J. Clin. Chem. Clin. Biochem.

Vol. 25, 1987, pp. $101-106$

(C) 1987 Walter de Gruyter \& Co.

Berlin - New York

\title{
Radioimmunoassay of 5-Hydroxy-3-indole Acetic Acid
}

\author{
By B. Manz, H. J. Grill, O. Belovsky, I. Kleinböhl, A. Heubner and K. Pollow \\ Abteilung für Experimentelle Endokrinologie der Johannes-Gutenberg-Universität Mainz
}

(Received May 20/August 25, 1986)

Summary: A direct radioimmunoassay of the methyl ester of urinary and serum 5-hydroxy-3-indole acetic acid is described. The antiserum, raised in a rabbit against a conjugate of bovine serum albumin with 5hydroxytryptamine hemisuccinamide, contained two antigenic fractions, one binding $\mathrm{N}$-acyl 5-hydroxytryptamine, and the other binding methyl ester of 5-hydroxy-3-indole acetic acid, and $\mathrm{N}$-acyl 5-hydroxytryptamine. The $\mathrm{N}$-acyl 5-hydroxytryptamine binding fraction was removed by affinity chromatography on a $\mathrm{N}$-acyl 5hydroxytryptamine agarose gel in the presence of excess methyl ester of 5-hydroxy-3-indole acetic acid. The antibody methyl ester of 5-hydroxy-3-indole acetic acid complexes were dissociated and this affinity-purified antiserum was used in all experiments. Polyethylene glycol in combination with goat anti-rabbit $\operatorname{IgG}$ was used to separate bound and unbound ${ }^{125}$ I-labeled Bolton-Hunter reagent- 5-hydroxytryptamine conjugate. Sample preparation (esterification of 5-hydroxy-3-indole acetic acid to its methyl ester) was performed with trimethylsilyldiazomethane in dioxane. In the analysis of urine, the reagents used in the methylation served as diluents, contributing to the final dilution of $1: 1100$. In the analysis of serum, a deproteination step (ethanol precipitation) prior to methylation was necessary to obtain reproducible results. The methylated 5hydroxy-3-indole acetic acid was then extracted with ethyl acetate and the extract redissolved in assay buffer. The minimal detectable concentration of methyl ester of 5-hydroxy-3-indole acetic acid was $1.1 \mu \mathrm{mol} / 1$ $(0.21 \mathrm{mg} / 1$ 5-hydroxy-3-indole acetic acid) urine or $100 \mathrm{fmol} /$ tube. The intra-assay precision $(\mathrm{CV})$ for urine samples was $6.4 \%(n=20)$ at a level of $22 \mu \mathrm{mol} / 1$, and $9.6 \%(n=20)$ at a level of $230 \mu \mathrm{mol} / \mathrm{l}$. The interassay CV was $11 \%$ at a level of $230 \mu \mathrm{mol} / \mathrm{l}$. The only substance cross-reacting with the antibody was $\mathrm{N}$ acetylserotonin which was not detectable in urine when the esterification step was omitted. To validate the clinical usefulness of this assay, a comparison with the commercially available BioRad ${ }^{\circledR}$ column assay was performed. Both radioimmunoassay and fluorescence determination accurately identified two patients with known carcinoid syndrome. A correlation of $r=0.817$ was demonstrated between the two assays in a comparison of normal and pathological urines. A simultaneous determination of serotonin and its metabolite 5-hydroxy-3-indole acetic acid in normal and pathological sera showed that both parameters were raised in carcinoid syndrome.

\section{Introduction}

Carcinoid tumours generally secrete various amounts of indoles. Many of them secrete other substances such as bradykinin, corticotropin, and histamine (1), but carcinoid syndrome is generally characterized by an increased urinary excretion of 5-hydroxy-3-indole acetic acid, the end product of serotonin metabolism (2). Traditionally, this compound is assayed by diazotization with nitrosonaphthol to form a purple colour (3). However, it is well documented that many other substances present in the urine interfere with this reaction to give false-positive results (4). Attempts were made to overcome this problem by a combination of ion exchange chromatography and fluorometry (BioRad ${ }^{\circledR}$ column test). This method, however, lacks sensitivity and is time consuming. Recently, high performance liquid chromatographic analyses of 5-hydroxy-3-indole acetic acid with fluorometry in the ultraviolet region of the spectrum (5) or electrochemical detection (6) have been described. Both methods require solvent extraction because of the numerous interfering compounds present in urine. 
Although the induction of antibodies against 5-hydroxy-3-indole acetic acid has been reported, the low titers of anti-5-hydroxy-3-indole acetic acid antisera $(7,8)$ or the complexity of the assay procedure $(9)$ has strictly limited their applicability. Based on the previously described radioimmunoassay of $\mathrm{N}$-acetylated 5-hydroxytryptamine (10), it was therefore decided to establish a radioimmunoassay for the determination of the methyl ester of 5-hydroxy-3-indole acetic acid in urine and serum, using a structurally related $\left[{ }^{125} \mathrm{I}\right] \mathrm{N}$-acyl analogue of 5-hydroxytryptamine. The specific conversion of 5-hydroxy-3-indole acetic acid into its methyl ester by trimethylsilyldiazomethane (11) and the use of a ${ }^{125} \mathrm{I}$ analogue as radioactive ligand in combination with the double antibody technique facilitate the determination of 5-hydroxy-3-indole acetic acid in a routine laboratory.

\section{Materials and Methods}

Reagents

\section{Chemicals}

N-Succinimidyl-3-(4-hydroxy-5(3)-[125I]iodophenyl)propionate (25I-labeled Bolton-Hunter reagent, $74 \mathrm{TBq} / \mathrm{mmol}$ ) and 5-hydroxy $\left[1,2-{ }^{3} \mathrm{H}(\mathrm{N})\right]$ tryptamine: creatinine sulphate (1.1 TBq/ mmol) were from New England Nuclear Corp. (Dreieich, F.R.G.). Bovine serum albumin was from Behring Institut (Marburg, F. R. G.). 5-Hydroxy-3-indole acetic acid and its analogues were from Sigma (München, F. R. G.) and Aldrich (Nettetal, F. R. G.). Analytical grade chemicals and glass-distilled water were used throughout.

\section{Buffers}

Buffers used are identified by the following abbreviations: buffer A $(50 \mathrm{mmol} / 1$ potassium phosphate, $\mathrm{pH} \mathrm{7.0,} \mathrm{containing}$ $3 \mathrm{mmol} / 1$ sodium azide and $1 \mathrm{~g} / \mathrm{l}$ ascorbic acid); buffer $\mathrm{B}$ (buffer A supplemented with $1 \mathrm{~g} / \mathrm{l}$ gelatine).

\section{Tracer solution}

Appropriate amounts of the ${ }^{125}$ I-labeled Bolton-Hunter reagent5-hydroxytryptamine conjugate diluted with buffer B to a final radioactivity of $10 \mathrm{MBq} / \mathrm{l}$.

\section{Antiserum solution}

The affinity purified antiserum was tested at different dilutions in buffer $\mathrm{A}$. The dilution resulting in $25 \%$ binding of the tracer under assay conditions was used.

\section{Precipitating antiserum reagent}

The precipitating antiserum (goat anti-rabbit IgG, polyethylene glycol 4000, sodium azide as preservative) was purchased from DDV Diagnostika (Marburg, F. R. G.).

\section{Preparation of immunogen and immunisation}

The immunogen used consisted of 5-hydroxytryptamine hemisuccinamide bound to bovine serum albumin as described $(9$, 11). Rabbits were immunized with an initial dorsal injection of an emulsion of $0.5 \mathrm{ml}(1 \mathrm{mg})$ of immunogen and $0.5 \mathrm{ml}$ of complete Freund's adjuvant. Booster injections were given in the same way at 4 week intervals except that incomplete Freund's adjuvant was used.

Iodination of 5-hydroxytryptamine ( ${ }^{125}$ I-labeled Bolton-Hunter reagent-5-hydroxytryptamine conjugate). Five mg of 5-hydroxytryptamine were dissolved in $500 \mu \mathrm{l}$ dry pyridine, $10 \mu \mathrm{l}$ aliquots of this solution were mixed with appropriate amounts of ${ }^{125} \mathrm{I}$ labeled Bolton-Hunter reagent and the conjugate purified by reversed phase high performance liquid chromatography as previously described (10).

Purification of anti-methyl ester of 5-hydroxy-3-indole acetic acid antibodies (affinity purified antiserum)

I. Preparation of 5-hydroxytryptamine affinity gel Commercially available Affigel 10 (BioRad, Richmond, USA) a $\mathrm{N}$-hydroxysuccinamide active ester derivative of cross-linked agarose beads, was used as activated support. 5-Hydroxytryptamine hydrochloride $\left(500 \mathrm{mg}\right.$ plus $1.8 \mathrm{MBq}\left[{ }^{3} \mathrm{H}\right] 5$-hydroxytryptamine; final specific activity $0.66 \mathrm{GBq} / \mathrm{mol}$ ) was dissolved in $20 \mathrm{ml}$ of $1 \mathrm{~mol} / 1 \mathrm{NaOH}$ and the free amine was extracted three times with $50 \mathrm{ml}$ of $\mathrm{CHCl}_{3}$. The organic solvent was evaporated in vacuo and the remaining oil dissolved in ethanol. The final concentration of 5-hydroxytryptamine was $1 \mathrm{~mol} / \mathrm{l}$. Affigel 10 was used without further purification. 5-Hydroxytryptamine solution $(2 \mathrm{ml})$ was added to a suspension of $25 \mathrm{ml}$ gel in $25 \mathrm{ml}$ ethanol and the reaction mixture was gently shaken overnight at $4{ }^{\circ} \mathrm{C}$. The gel was recovered by filtration and washed with 21 of buffer A. Based on the specific activity of the affinity gel (determined after solubilization of $0.5 \mathrm{ml}$ of gel suspension with $30 \% \mathrm{H}_{2} \mathrm{O}_{2}$ ), approximately $5 \mathrm{mmol} 5$-hydroxytryptamine were covalently bound per litre of gel. In the presence of $1 \mathrm{~g} / 1$ ascorbic acid the gel was stable for several months at $4{ }^{\circ} \mathrm{C}$.

\section{Affinity chromatography}

Affinity chromatography was performed as previously described (12). Briefly, $10 \mathrm{ml}$ of antiserum were diluted with $90 \mathrm{ml}$ of buffer $A$ and incubated with $1 \mathrm{mg} / \mathrm{l}$ of methyl ester of $5=$ hydroxy-3-indole acetic acid for $2 \mathrm{~h}$ at $37^{\circ} \mathrm{C}$. Affinity gel $(1 \mathrm{~g})$ was added and the mixture rotated for $18 \mathrm{~h}$ at $4{ }^{\circ} \mathrm{C}$. The suspension was poured into a sintered glass funnel and the filtrate collected. In order to remove excess methyl ester of 5hydroxy-3-indole acetic acid, the eluate was incubated for $5 \mathrm{~h}$ with $5 \mathrm{ml}$ of protein A sepharose (Pharmacia, Sweden), followed by a short washing step in a sintered glass funnel. To release the protein A-bound $\mathrm{IgG}$, the affinity gel was eluted with two volumes of $0.1 \mathrm{~mol} / 1$ acetic acid. The eluate was collected directly into $0.5 \mathrm{~mol} / 1$ disodium phosphate to neutralize the $\mathrm{pH}(13), 10 \mathrm{ml}$ of rabbit preimmune serum were added, and the solution was dialysed against phosphate buffered saline, then lyophilized. The lyophilized anti-methyl ester of 5-hydro$x y-3$-indole acetic acid antibody-enriched serum (affinity purified antiserum) was dissolved in $10 \mathrm{ml}$ of distilled water and stored at $-20^{\circ} \mathrm{C}$ until use.

\section{Sample preparation}

Urine

Aliquots of acidified $24 \mathrm{~h}$ urine were stored in the dark at about $4^{\circ} \mathrm{C}$, or frozen if analysis was more than $48 \mathrm{~h}$ later. Lyophilized quality control samples (Lypho Check ${ }^{\circledR}$, Anaheim, California, USA) were reconstituted with $0.1 \mathrm{~mol} / 1 \mathrm{HCl}$ and stored frozen at $-20^{\circ} \mathrm{C}$.

\section{Conversion of 5-hydroxy-3-indole acetic acid to its methyl ester}

Urine specimens $(100 \mu \mathrm{l})$ were diluted with $2 \mathrm{ml}$ of methanol. This diluted urine $(100 \mu l)$ was added to a conical glass tube, followed by $25 \mu$ l of a $18 \%$ solution of trimethylsilyldiazome- 
thane in dioxan (Ventron, Karlsruhe, F. R. G.). Excess reagent was destroyed by addition of $25 \mu \mathrm{l}$ of $0.1 \mathrm{~mol} / \mathrm{l} \mathrm{HCl}$. The methylated probe was then further diluted with $5 \mathrm{ml}$ of buffer $\mathrm{B}$, and $100 \mu \mathrm{l}$ aliquots were withdrawn for radioimmunoassay.

\section{Serum}

To avoid clotted fibrin, blood samples were collected by use of Monovette syringes (Sarstedt, Nümbrecht, F. R. G. or similar products), and centrifuged at $1500 \mathrm{~g}$. The serum was separated and frozen at $-20^{\circ} \mathrm{C}$ before analysis (within two weeks). All samples were taken only during normal waking hours, but at no specific time.

\section{5-Hydroxy-3-indole acetic acid extraction and conversion to its methyl ester}

Serum $(200 \mu \mathrm{l})$ and ethanol $(400 \mu \mathrm{l})$ were added to a glass tube and carefully vortexed. The mixture was kept for $30 \mathrm{~min}$ at $4^{\circ} \mathrm{C}$ to complete the precipitation of proteins, then centrifuged at $2000 \mathrm{~g}$. Clear supernatant $(400 \mu \mathrm{l})$ was decanted into a glass tube. Methanol $(200 \mu \mathrm{l})$ and $18 \%$ trimethylsilyldiazomethane in dioxan $(50 \mu \mathrm{l})$ were added and the mixture kept for $10 \mathrm{~min}$ at room temperature. $\mathrm{HCl}(0.1 \mathrm{~mol} / 1,50 \mu \mathrm{l})$ and water $(2 \mathrm{ml})$ were added and the methylated 5-hydroxy-3-indole acetic acid extracted with $4 \mathrm{ml}$ of ethyl acetate. An aliquot of the organic extract $(3 \mathrm{ml})$ was withdrawn and the solvent removed by evaporation under a gentle stream of nitrogen. Assay buffer $(250 \mu \mathrm{l})$ was added and the 2.5 -fold diluted extract stored at $0-4^{\circ} \mathrm{C}$ until use (no longer than 1 month).

\section{Radioimmunoassay procedure}

The methylated urine or serum preparation $(100 \mu \mathrm{l})$, tracer solution $(100 \mu \mathrm{l}, 1 \mathrm{kBq} /$ tube) and diluted affinity purified antiserum $(100 \mu \mathrm{l}$, final dilution $1: 600)$ were added to a polystyrene tube and incubated overnight at $4^{\circ} \mathrm{C}$. One $\mathrm{ml}$ of precipitating antibody was added, the mixture incubated for $1 \mathrm{~h}$ at $4^{\circ} \mathrm{C}$ and centrifuged. The supernatant was aspirated and the pelleted radioactivity determined in a gamma-counter. Each series consisted of a standard curve $(0.0052-0.52 \mu \mathrm{mol} / \mathrm{l}$ methyl ester of 5-hydroxy-3-indole acetic acid), blanks for the determination of unspecific binding, quality control samples and the samples to be assayed. The serum values were corrected for dilution during sample preparation by multiplying by 2.5 .

\section{Results}

\section{Antibody preparation}

Approximately 50 percent of the previously reported polyclonal anti $\mathrm{N}$-acetylserotonin antibodies are able to bind methyl ester of 5-hydroxy-3-indole acetic acid with high affinity (fig. 1) whereas all antibodies are able to bind $\mathrm{N}$-acyl analogues of 5-hydroxytryptamine (10). This property was used to separate the methyl ester of 5-hydroxy-3-indole acetic acid binding fraction from the exclusively $\mathrm{N}$-acyl 5-hydroxytryptamine binding fraction by affinity chromatography. As the affinity gel consisted of 5-hydroxytryptamine coupled to activated carboxyl groups of crosslinked agarose, only the $\mathrm{N}$-acyl 5-hydroxytryptamine

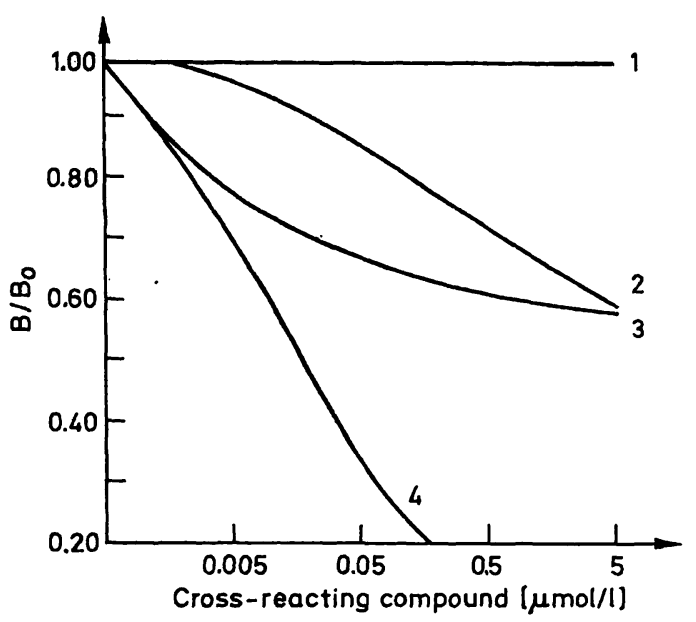

Fig. 1. Inhibition by 5-hydroxytryptamine analogues of binding of ${ }^{125}$ I-labeled Bolton-Hunter-5-hydroxytryptamine conjugate by antibody.

Aliquots of diluted antiserum $(100 \mu \mathrm{l})$ were incubated in triplicate with tracer solution $(100 \mu \mathrm{l}, 1 \mathrm{kBq} / \mathrm{tube})$ and increasing concentrations $(0-5 \mu \mathrm{mol} / \mathrm{l})$ of the various competitors. Antibody-bound radioactivity was determined by use of the double antibody technique. The numbers represent: (1) 5-hydroxy-3-indole acetic acid; (2) 5-hydroxytryptophol; (3) methyl ester of 5hydroxy-3-indole acetic acid; (4) 5-hydroxytryptamine (non-radioactive Bolton-Hunter-5-hydroxytryptamine conjugate, see table 2).

binding fraction was retained on the gel in the presence of excess methyl ester of 5-hydroxy-3-indole acetic acid.

The methyl ester of 5-hydroxy-3-indole acetic acidmasked antibody fraction was isolated by a second affinity chromatography step. As protein A sepharose specifically binds to the $\mathrm{Fc}$ region of the IgG molecule, a dialysis step was necessary to isolate methyl ester of 5-hydroxy-3-indole acetic acid-free antibodies. The affinity purified antibodies were supplemented with preimmune serum to enhance the precipitation efficiency of the second anti-rabbit IgG antibodies during the radioimmunoassay procedure.

Esterification of 5-hydroxy-3-indole acetic acid to its methyl ester

The esterification of indole acids with trimethylsilyldiazomethane and methanol proceeds instantaneously when an excess of the reagent is used, and the reaction can be easily monitored by the disappearance of the yellow colour (tab. 1). For diluted urine specimens, most of the reagent was needed to destroy the hydrochloric acid which was added to the urine to stabilize the 5-hydroxy-3-indole acetic acid. Saponification of the ester bond under assay conditions was not observed. 
Tab. 1. Esterification of some carboxylic acids with trimethylsilyldiazomethane.

\begin{tabular}{lll}
\hline $\mathrm{R}-\mathrm{COOH}$ & Isolated yield of \\
& & $\mathrm{R}-\mathrm{C}-\mathrm{O}-\mathrm{CH}_{3}$ \\
\hline 1 & 5-Hydroxy-3-indole acetic acid & Quantitative \\
2 & Indole-3-acetic acid & Quantitative \\
3 & Indole-3-pyruvic acid & Quantitative \\
4 & 3-Indole acrylic acid & Quantitative \\
5 & $D, L$-Vanillylmandelic acid & Quantitative \\
6 & Homovanillic acid & Quantitative \\
\hline
\end{tabular}

A general experimental procedure for the preparation of methyl esters is as follows: Trimethylsilyldiazomethane $(0.13 \mathrm{mmol})$ in $100 \mu$ l of dioxan was added to a stirred solution of the carboxylic acid $(0.1 \mathrm{mmol})$ in methanol $(5 \mathrm{ml})$ at room temperature. The mixture was concentrated and the purity was checked by thin-layer chromatography on Merck F-254@ (Merck, Darmstadt, F. R. G.) precoated silica gel plates in solvent systems chloroform/methanol $(9+1$, by vol.), ethyl acetate/ ethanol/ $\mathrm{NH}_{3}(5+5+1)$, and $n$-butanol/acetic acid/ $\mathrm{H}_{2} \mathrm{O}$ $(12+3+4$, by vol. $)$.

\section{Standard curve}

A typical standard curve is shown in figure 2. The standard curve is sigmoid over the range of $0.47-47$ $\mathrm{pmol} / \mathrm{tube}$. As the sample preparation includes a 1100 -fold dilution of urine specimen, the standard curve actually covers the range of $5.2-520 \mu \mathrm{mol} / 1$ urine.

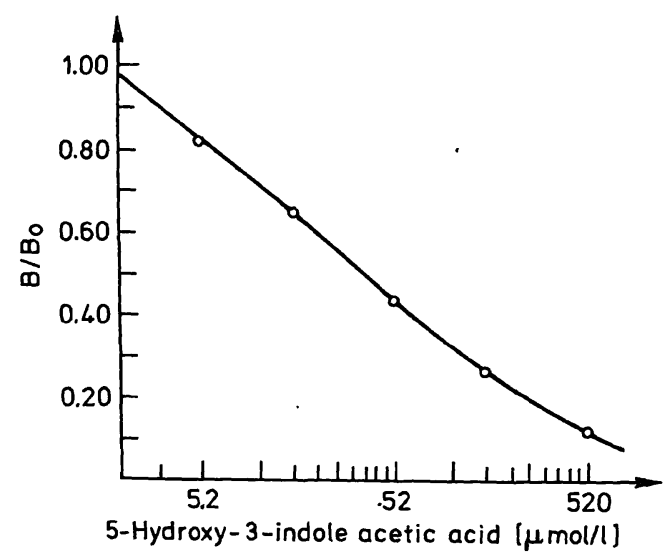

Fig. 2. Typical standard curve for the radioimmunoassay of methyl ester of 5-hydroxy-3-indole acetic acid.

The abscissa represents the concentrations of methyl ester of 5-hydroxy-3-indole acetic acid in the standards corrected for the 1100 -fold dilution of urine during sample preparation.

\section{Minimum detectable concentration}

-The within-day CV of the zero-dose standard is $<2 \%$. Therefore, the minimal detectable concentration is the concentration at which $\mathrm{B} / \mathrm{B}_{\mathrm{o}}$ is approximately $0.96(1-2 \mathrm{CV})$, or $1.1 \mu \mathrm{mol} / \mathrm{l}$ urine $(0.1 \mathrm{pmol} /$ tube).

\section{Specificity}

The specificity of antibody for methyl ester of 5hydroxy-3-indole acetic acid is shown in table 2 . The data indicate that in addition to acylation of the amino group of 5-hydroxytryptamine (10), esterification of the carboxy group of .5-hydroxy-3-indole acetic acid is also a prerequisite for the specific recognition of the 5-hydroxyindole nucleus by this antibody.

Tab. 2. Specificity of anti-methyl ester of 5-hydroxy-3-indole acetic acid.

\begin{tabular}{ll}
\hline Compound & $\begin{array}{l}\text { Cross } \\
\text { reaction } \\
{[\%]^{*}}\end{array}$ \\
\hline 5-Hydroxy-3-indole acetic acid methyl ester & 100 \\
5-Hydroxy-3-indole acetic acid & $<0.1$ \\
Indole-3-acrylic acid & $<0.01$ \\
Indole-3-acrylic acid methyl ester & $<4$ \\
Indole-3-pyruvic acid & $<0.01$ \\
Indole-3-pyruvic acid methyl ester & $<0.4$ \\
Indole-3-acetic acid & $<0.1$ \\
Indole-3-acetic acid methyl ester & $<2$ \\
5-Hydroxytryptamine & $<0.1$ \\
N-[3-(4-hydroxy-3(5)-iodophenyl)-propionyl]- & \\
5-hydroxytryptamine & 900 \\
N-Acetylserotonin & 800 \\
5-Hydroxy- $D, L$-tryptophan & $<0.1$ \\
5-Hydroxy- $D, L$-tryptophan methyl ester & $<0.1$ \\
5-Hydroxytryptophol & $<3$ \\
Tryptamine & $<0.1$ \\
Melatonin & $<1$ \\
5-Methoxytryptophol & $<0.01$ \\
5-Methoxytryptamine & $<0.01$ \\
$D, L$-Vanillylmandelic acid & $<0.01$ \\
$D, L$-Vanillylmandelic acid methyl ester & $<0.01$ \\
\hline
\end{tabular}

*) The percent cross reaction is determined by dividing the mass of methyl ester of 5-hydroxy-3-indole acetic acid at $0.5 \mathrm{~B} / \mathrm{B}_{\circ}$ by the mass of the cross-reacting compound at 0.5 $\mathrm{B} / \mathrm{B}_{\mathrm{o}}$ and multiplying by 100 .

The specificity of antibody for methyl ester of 5hydroxy-3-indole acetic acid in methylated serum extracts is shown in figure 3. Reversed phase high performance liquid chromatography reveals only one peak detectable by radioimmunoassay. The retention time of this peak is identical with that of authentic methyl ester of 5-hydroxy-3-indole acetic acid.

\section{Recovery}

\section{Urine}

Twenty different urine specimens were tested. Aliquots were enriched with 26 and $52 \mu \mathrm{mol} / 1$ 5-hydroxy3-indole acetic acid, and the differences between enriched and normal urines determined by radioimmunoassay. Analytical recoveries were $99 \%$ (SD $5.4 \%$ ) and $101 \%$ (SD 7.4\%), respectively. 


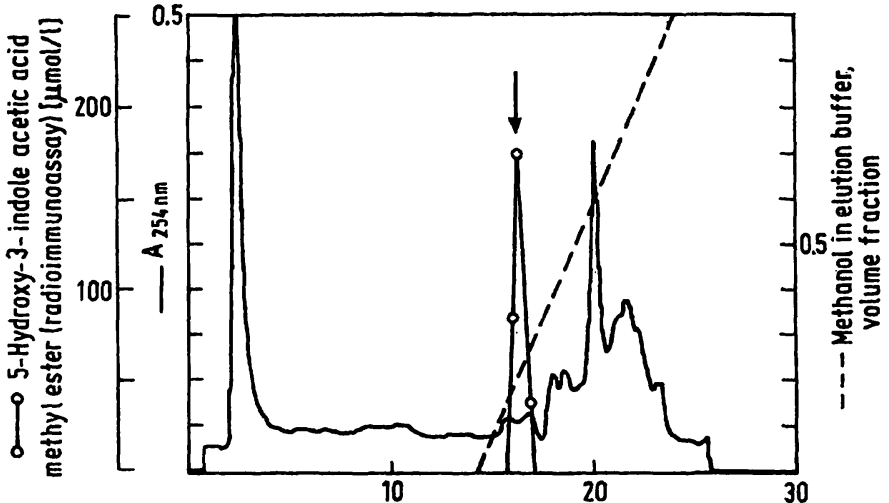

Fig. 3. High performance liquid chromatography of a human serum extract (carcinoid syndrome).

Human serum $(1 \mathrm{ml})$ and ethanol $(2 \mathrm{ml})$ were mixed, the precipitated proteins removed by centrifugation and the supernatant methylated and extracted with ethyl acetate as described in Material and Methods. In contrast to the radioimmunoassay procedure, the methylated extract was redissolved in water/methanol $(9+1$, by vol.) and submitted to reversed phase high performance liquid chromatography on a PEP RPC column (Pharmacia, Freiburg, F. R. G.). Fractions of $1 \mathrm{ml}$ were collected for the determination of methyl ester of 5hydroxy-3-indole acetic acid by radioimmunoassay. The arrow $(\downarrow)$ indicates the retention time of authentic methyl ester of 5-hydroxy-3-indole acetic acid.

\section{Serum}

Pooled human serum was enriched with 0.52 and $2.6 \mu \mathrm{mol} / 15$-hydroxy-3-indole acetic acid, and the differences between enriched and pooled sera determined by radioimmunoassay. Analytical recovery was $>85 \%$.

\section{Precision}

Twenty urine specimens from a normal volunteer and Lypocheck ${ }^{\circledR}$ Control Urine II C (Lot. No. 00200) were stored in the dark at $-20^{\circ} \mathrm{C}$ and used to estimate the intra- and inter-assay precision. The intraassay $\mathrm{CV}$ for $22 \mu \mathrm{mol} / 1$ (normal volunteer) and 230 $\mu \mathrm{mol} / \mathrm{l}$ (control urine) was $6.4 \%$ and $9.6 \%$, respectively ( 29 consecutive determinations). The inter-assay CV was $11 \%$ for $230 \mu \mathrm{mol} / 1$.

Fluorescence assay of urinary 5-hydroxy-3indole acetic acid

A comparison of the BioRad ${ }^{\circledR}$ column test (a combination of ion exchange chromatography and chemical transformation of the partly purified acid to a fluorochrome with subsequent fluorescence measurement) and the radioimmunoassay showed the following correlation between both methods (tab. 3). Linear regression analysis of the data: $r=0.842, y$-intercept $=7.3$, slope $=0.817$.
Tab. 3. Comparison of 5-hydroxy-3-indole acetic acid radioimmunoassay and the BioRad ${ }^{\circledR}$ column test ${ }^{\mathrm{a}}$ ).

\begin{tabular}{|c|c|c|c|c|c|}
\hline \multirow{2}{*}{$\begin{array}{l}\text { Sample } \\
\text { No. }\end{array}$} & BioRad & RIA & \multirow{2}{*}{$\begin{array}{l}\text { Sample } \\
\text { No. }\end{array}$} & BioRad & RIA \\
\hline & \multicolumn{2}{|l|}{$(\mu \mathrm{mol} / \mathrm{l})$} & & \multicolumn{2}{|l|}{$(\mu \mathrm{mol} / \mathrm{l})$} \\
\hline 1 & 67.5 & 57.6 & 16 & 0.52 & 24.6 \\
\hline 2 & 62.8 & 62.3 & 17 & 20.9 & 28.7 \\
\hline 3 & 18.8 & 25.1 & 18 & 20.9 & 12 \\
\hline 4 & 18.8 & 15.7 & 19 & 9.4 & 5.8 \\
\hline 5 & 21.4 & 17.2 & 20 & 16.2 & 15.7 \\
\hline 6 & 21.4 & 13.6 & 21 & 16.2 & 23.5 \\
\hline 7 & 14.6 & 14.9 & 22 & 14.6 & 19.3 \\
\hline 8 & 14.6 & 20.4 & 23 & 14.6 & 37.6 \\
\hline 9 & 18.8 & 29.8 & 24 & [off curve & $\left.\left.581^{b}\right)\right]$ \\
\hline 10 & 18.8 & 20.9 & 25 & [off curve & $\left.\left.371^{b}\right)\right]$ \\
\hline 11 & 4.7 & 6.3 & 26 & 10.4 & 13.6 \\
\hline 12 & 4.7 & 13.6 & 27 & 28.2 & 35.1 \\
\hline 13 & 20.9 & 25.1 & 28 & 29.3 & 42.9 \\
\hline 14 & 5.2 & 2.8 & 29 & 35.6 & 45 \\
\hline 15 & 28.7 & 24.6 & 30 & {$[214$} & $\left.\left.230^{c}\right)\right]$ \\
\hline
\end{tabular}

$\mathrm{y}=7.30+0.817 \mathrm{x} ; \mathrm{r}=0.842$

a) Fluorescence measurement

b) Patients with known carcinoid syndrome

c) Lyphocheck ${ }^{\circledR}$ Control Urine II, Lot. No. 00200

[] Values in square brackets were not used for the determination of the correlation coefficient

Tab. 4. Determination of 5-hydroxy-3-indole acetic acid in urine and serum of three healthy donors and two patients with carcinoid syndrome.

\begin{tabular}{lcll}
\hline & \multicolumn{2}{l}{$\begin{array}{l}\text { 5-Hydroxy-3-indole } \\
\text { acetic acid } \\
\text { concentration }(\mu \mathrm{mol} / \mathrm{l})\end{array}$} & $\begin{array}{l}\text { Serotonin } \\
\text { concentration } \\
(\mu \mathrm{mol} / \mathrm{l})\end{array}$ \\
\cline { 2 - 4 } & Urine & Serum & Serum \\
\hline S.H. & 18.8 & 0.72 & 0.64 \\
I.K. & 20.9 & 0.81 & 0.46 \\
A.H. & 14.6 & 0.3 & 0.85 \\
Sample 24b) & 581.0 & 5.23 & 6.2 \\
Sample 25 & 371.0 & 5.75 & 5.05 \\
\hline
\end{tabular}

a) Determined by a commercially available radioimmunoassay (DDV Diagnostika, Marburg, F. R. G.)

b) See Table 3.

\section{Discussion}

We determined 5-hydroxy-3-indole acetic acid by radioimmunoassay, because this method is faster, more sensitive and more specific than previously described methods $(1-9)$. The determination of the methyl ester of 5-hydroxy-3-indole acetic acid has several additional advantages: firstly, esterification prior to radioimmunoassay strictly limits the number of possible cross-reacting compounds to carboxylic acids; secondly, endogenous $\mathrm{N}$-acetylserotonin, a minor metabolite of 5-hydroxytryptamine (14), which could falsify the assay is detectable by direct comparison 
of esterified and normal urine. Nevertheless, neither $\mathrm{N}$-acetylserotonin nor any other cross-reacting unknown substance was found in normal and pathological urines under assay conditions.

The present investigation shows that the radioimmunoassay of esterified 5-hydroxy-3-indole acetic acid is highly sensitive for the analysis of 5-hydroxy3-indole acetic acid in a variety of urine samples as well as in serum. The good coefficients of variation exhibited by the method should facilitate the examination and comparison of groups that differ only slightly from one another with respect to 5-hydroxy3-indole acetic acid levels.

\section{References}

1. Oates, J. A. \& Butler, T. C. (1967) Adv. Pharmacol. 5, 109-114.

2. Udenfriend, S., Weissbach, H. \& Clark, C. T. (1955) J. Biol. Chem. 215, 337-344.

3. Udenfriend, S., Titus, E. \& Weissbach, H. (1955) J. Biol. Chem. 216, 499-505.

4. Young, D. S., Thomas, D. W., Friedman, R. B. \& Pestaner, L. C. (1972) Clin. Chem. 18, 1268-1276.

5. Anderson, G. M. \& Purdy, W. C. (1979) Anal. Chem. 5I, 283-289.

6. Shihabi, Z. K. \& Scaro, J. (1980) Clin. Chem. 26, 907909.

7. Ranadive, N. S. \& Sehon, A. H. (1967) Can. J. Biochem. 45, 1689-1699.

8. Ranadive, N. S. \& Sehon, A. H. (1967) Can. J. Biochem. $45,1701-1710$.
9. Delaage, M. A. \& Puizillout, J. J. (1981) J. Physiol. 77, $339-347$.

10. Manz, B., Kosfeld, H., Harbauer, G., Grill, H.-J. \& Pollow, K. (1985) J. Clin. Chem. Clin. Biochem. 23, 657=662.

11. Manz, B., Schüler, G. \& Pollow, K. (1986) Acta Endocrinol. Suppl. 274, vol. 111, p. 235.

12. Manz, B., Grill, H.-J., Köhler, I., Heubner, A. \& Pollow, K. (1982) Eur. J. Biochem. 128, 249-255.

13. Al-Shawi, A., Mohammed-Ali, S., Houts, T., Hodgkinson, S., Nargessi, R. D. \& Landon, J. (1981) The Ligand Quarterly 4, 43-51.

14. Rollay, M. D. (1983) Methods for measuring pineal hormones (Reiter, R. J., ed.) CRC Press, Boca Raton, Florida, pp. 274-298.

Dr. Bernhard Manz

Abteilung für Experimentelle Endokrinologie

Johannes Gutenberg-Universität

Langenbeckstr. 1

D-6500 Mainz 